\title{
A Re-Interpretation of African Philosophical Idea of Man and the Universe: The Yoruba Example
}

\author{
Michael Aina Akande \\ Department of Philosophy, Lagos State University, Ojo, Nigeria \\ Email: ainaakande@yahoo.com
}

Received September $6^{\text {th }}$, 2012; revised October $8^{\text {th }}$, 2012; accepted October $23^{\text {rd }}, 2012$

\begin{abstract}
The concern of this paper is to argue against Maduabuchi Dukor's conception of African philosophical ideas of man, universe and God as "theistic humanism". Dukor's submission is an anti-thesis of the claims by many pioneer scholars in African philosophy who claimed that if Africans do not live in a religious universe perhaps one can affirm that their universe is theistic. But indeed the Africans' perceptions and attitude to life in their various manifestations reveal an idealistic metaphysical orientation without an attenuation of humanistic elements. It is argued in this paper that Dukor's philosophical idea of reality in the African context though contributes to knowledge, it is in sharp contrast to African metaphysical theories such as Placide Temple's theory of vital forces, Olubi Sodipo's theory of mystical causality, Dagogo Idoniboye's theory of spiritism among others. Even Sophie Oluwole, who argues that the Yoruba idea of morality is humanistic, still concludes that in moral issues the gods act as agent of sanction. In situating the African idea of reality in context, the Yoruba example is used in this paper with a view to establishing, contrary to Dukor's "theistic humanism"; that reality among the Yoruba is better construed as "humanistic theism”.
\end{abstract}

Keywords: African Belief; Theistic Humanism; Humanistic Theism; Yoruba

\section{Introduction}

It is no news that all the continents of the world have one religious belief or the other. Most of these religious beliefs are inadvertently tied to our views of life and the origin of the universe. It is good to note that not all religious beliefs are tied to the idea of a supreme being, Confucianism, Buddhism, Marxism, even Humanism have been labeled Godless religions.

Whether God is with us here or not, one can still ask is He concerned with human well-being? What is his thought towards the aspirations and desires of human beings who seem to play a major role in the affairs of the universe? Our concern here is whether the love of God can accommodate the love of man, or rather whether obeying God or the gods can lead man to a successful life of peace and harmony or whether human intellect and experience are enough tools to solve all human problems. Though most religions and their leaders would answer that obedience to God or the gods would lead to good life for man because God is both omnibenevolent and omniscient. However most of these religious leaders do the contrary in the name of God, their positions on various issues that concern human beings have degraded man and put man in somewhat pathetic situation, especially on issues like abortion, suicide, alms giving and war and the general notion of what goodness is. This sparked of the religious opposition of the 20th century that led to the pursuant of human ideals rather than theistic ideals.

Theistic Humanism to our mind, is the belief that the love of man involves the love of God, here man dictates the value for God to approve. While Humanistic Theism says the love of God involves the love of man and as such God dictates the value for man to approve. Theistic Humanism and Humanistic Theism are therefore compatibilist approach to value judgment.
The main controversy between humanists and theists is primarily ethical and epistemological as we suggested above. How one answer the question what is the source of value? Will determine where one belongs.

Those who said Theism and Humanism are contradictory see man purely from the physical part and see God as purely a spiritual being without the thought that humans could possess two personalities: body and soul, physical and mental. Though there is no finality on the issue of human personality but if human are composed of both body and soul, the human soul would have a way communicating with other souls, which the soul of God is one. This would afford us to know the will and plan of God for man and the universe. Also, it is possible for God or the gods to live by human rules, though this may raise certain epistemological and metaphysical problems like issues of superiority in intelligence and ability. Instead of holding to the above position, we would rather say that it is possible for God to approve rules made by man for man. One cannot adequately discuss this issue without taking into consideration the roles of religions and religious leaders who are supposedly God's representatives on earth. The various interpretations of what God or the gods want, and what their natures are have generated vain controversy. Their views about whether God is a man or woman, white or black, short or tall, big or small, would not be important here because this is subject to cultural affiliation and bias. Rather we shall take the personality that is moral and epistemic: omniscient, omnipotent, omnibenevolent, etc., which are mostly common in the descriptions of God in most cultures.

Maduabuchi Dukor argues in his book Theistic Humanism of African Philosophy that though Humanism and Theism appear contraries yet both can be true in Africa and Asian cultures. So, 
it is possible, to maintain the existence of a personal God and still believe human interests are important (2010: p. 100). Theistic Humanism is therefore, a dualist's explanation of the roles of man to himself and the universe. This paper maintains this dualist conception, but attempts to show that African philosophical idea of man, universe and God is "Humanistic Theism" rather than "Theistic Humanism". This is so because, one, we believe Dukor missed the essence of the controversy between humanism and theism. Two, he misinterpreted the sort of relationship between humanism and theism. For a proper understanding of the issue we shall make clarification of some important concepts.

\section{Clarification of the Concepts of Theism and Humanism}

Theism is the belief that God or a supreme being exists, who is the maker and the controller of the universe and everything within it. There are different variants of this belief with different supporting arguments. This God is the reason for the assumption that human beings have both a spiritual and a physical part with "a supernatural destiny” (Manuel Velaquez, 2005: p. 279).

There are various strand of theism: Monotheism, Polytheism, Pantheism and Panentheism. According to Spinoza, a pantheist, God is a whole that gathers up into itself all that exists. He believes that there is only one substance, a single connected system that is all-inclusive, and that this substance is God or Nature. In such a system as Spinoza's there is no question of whether theism is compatible with humanism or not. (Honer, Hunt \& Okholm, 1999: p. 141) Though this idea is also monotheistic, it differs from traditional monotheism that severs the relationship between the physical and the spiritual. No wonder Dukor accuses the Western religions as responsible for the controversy because they are traditionally monotheistic (Dukor, 2010: p. 100).

Humanism is a philosophy that is man centred. In humanism God is replaced by man. Though there are different definitions and perspectives to humanism, however, the common denomination is that man is "a source or center of values." (Honer, Hunt, \& Okholm, 1999: p. 145). This Protagorean saying that, "man is the measure of all things..." motivates early humanists to seek refuge in the capacity and intelligence of man in solving their immediate and remote problems (flood, earthquake, drought, famine and moral).

The opposition between early humanists and theists cannot be separated from the activities of church fathers and religious priests in sacrificing man and his aspirations on the altar of religious injunctions and beliefs. This opposition has led to a new form of religious approach known as Religious Humanism, which can be separated from Theistic Humanism. Also, the roles of modern science and technology that show-cased the efforts of human beings to unravel mysteries and create conducive atmosphere for good life, created early form of humanism called secular Humanism.

However, the controversy between Humanism and Theism is the question of whose interest or value should be paramount? Theism answers that God and Humanism says Man. It is the resolve of this paper that a merger or middle point is possible, that is one can provide a synthesis between this contraries; where both interests can be achieved.

\section{Why Is There a Relationship between Man and God?}

A quick look at African cosmology and the myths of creation painted a beginning when men and God were together but because of the attitude of man to assert himself against God's instructions, God separated himself from the earth to avoid man's disturbance. When God retires to a distant place in heaven, the onus is on man to care for himself and the universe which he inhabits. This is also illustrated in an ifa corpus where the divinities attempted to assert themselves and they told God to abdicate his throne and allow them rule for a period of sixteen years. God assented to their request but advised them to start with sixteen days in the first instance. The gods were happy and by the eighth days of their ruling everything stopped working. On the sixteenth day they apologized to God and restored his throne back. According to this story, immediately everything came back to normal (Okedairo, 2006: p. 41).

Part of human efforts in the affairs of the universe is the constitution of governments and societies or groups to take care of their affairs and everything that concern their well-being: regulation of environmental and social activities for the proper workings of nature.

The aspirations and interests of human beings are the possession of means of survival, attainment of the values set by society and the preservation of the universe for the survival of the future generation of man. But events and incidents in society especially Africa, proved the inability of government and consequently man to solve the problems of life. The man to man relationship did not help much. What we witness is the exploitation of man by man. The subjugation and oppression of the poor by the rich, and most importantly the disparity between work (effort) and wealth (success). Success in the human society is hardly determined by hard-work or resilience: someone may be rich today and become poor tomorrow and vice versa. Human intelligence therefore seems inadequate to solve all problems.

Fortunately also, Africans see God as the creator of the universe who has the interest of his creature at heart. The anthropomorphic conception of God painted HIM as omniscient, omnibenevolent, omnipotent, etc. God in this light can do all things especially if humans call on him with prayer and sacrifices. So, human beings (especially the disadvantaged, who are the masses) turned to God for provisions and protection. Needless to say here that in the anthropomorphic view of God humanity is not lost because the essence of God is the use of his powers for human progress. But the issue is whether God has holistic view of the universe or whether he takes particular interest in individual events and happenings in the universe. The problem between individualism and holism resurfaced here in the sense that there is a need to determine whether the interest of the whole is tantamount to that of the individuals in the society or whether the pursuant of individual interests would be to the benefit of the society. And it has been shown in experience that individual interest at times conflicts and it is in the society's interest that such conflict should dissolve. So, it is possible for society's interest to be achieved while that of the individual is lost.

For the above reason, some philosophers have argued that theism is not compatible with humanism, because theism is God centered (holistic) while humanism is man centered (individualistic). God is above man with the attributes of omnis- 
cience, Omni benevolent and omnipotence; He takes a holistic look of the universe and as such may not take the immediate interests of man into consideration, if it would affect his overall plan for the universe, since man is not the only occupant of the physical world. Africans feel otherwise because the hope reposes in the provisions and the judgments of the gods or God is stronger than that reposed in man. Dukor's submission by the understanding of this paper is that Africans believe that man is the source of value, i.e. man makes the rules that God would approve. But this paper is an attempt to show that contrary to this, Africans believe that God makes the rules that human would approve. Godwin Azenabor (2010: p. 40) while analyzing Placide Temple's position on African Philosophy writes that:

A stronger force normally influences the weaker or inferior and the latter is more or less at the service of the stronger. The superior can influence the inferior directly, while the inferior can influence the superior only indirectly. It is this ontological relationship among life forces that do not permit the Africans to see things in isolation.

Maduabuchi Dukor (2001) sees the inclusion of humanism in theistic belief. Which means that one can hold the belief that it is better to obey human values in all things and still feels the interests of God is indispensable, because the interest of God is not against that of man. According to him, the idea of theism and humanism is jointly and inseparably applicable to African culture. Dukor writes that: Theistic Humanism is based on the belief that Theism and Humanism are both compatible and harmonious elements of black metaphysical and epistemological world-view (Dukor, 2010: p. 100). But in his interpretation he gave pre-eminence to human value over and above theistic value. Also, Sophie Oluwole (1984: pp. 14-25) argues that values in Yoruba culture are product of human rationality. She supported her argument with the allegory of the snail and the tortoise. In that story, the Tortoise was the in-law of the Snail, but when condition of life became terrible for the tortoise, he decided to go stealing from his in-laws farm. One day he was caught and his in-law decided to put him to shame by tying him to a tree near the footpath that goes to the market. The belief was that he will be chastised for this wrong act. Though, he was blamed while the people were going to the market in the morning. Surprisingly while they were coming in the evening the blame came on the Snail. The lesson here is that the Yoruba holds a relativistic theory of value based on human predicament and suffering.

While one did not dispute this, one can still argued that the source of that value judgment is a product of their religion. A great look through ifa corpus which stands as the holy book of the Yorubas also attests to this relative attitude of value judgment, knowing fully well that all of those market men and women are devotees of one god or the other.

Though, some theistic beliefs tend towards absolutism which is incongruous with the relative notion of human needs, this, sometimes, results into fundamentalism on the part of religious leaders and followers but there are others that are appropriate for human emancipation. We think here that, African (poly) theism does not harbor such absolute ideals for the following reasons: One, because of the opportunity of choosing among various gods, two, because the gods are believed to have their own limitations, yet this limitation supersedes human intelligence. The gods are aware of human needs that are necessary for their development. They are also aware of the power of their adherent to protest and rebel if these needs were not met. This shall be made clear in the exposition of African beliefs about God and the universe.

\section{The African Conception of God and the Universe}

God is one controversial figure that human beings have to contend with his existence or otherwise. There are various arguments that point to the existence of God, some based on reason while others on mythology. Whichever we hold, it is borne out of different experiences of man within the universe.

The issue of whether Africans have philosophy or not is before this century a closed debate, because African scholars and philosophers like Odera Oruka, Bodunrin, Moses Makinde, Sophie Oluwole have in their different ways substantially show philosophical ingredients embedded in African myth, folklores, proverbs, and wise-sayings. (Dukor, 2010: p. 89) The issue now is what sort of philosophy can properly be labeled African?

There have been different interpretations as to what it is, many of these are monistic in nature: theistic, religious or humanistic. However our concern is on Maduabuchi Dukor's interpretation which sees African Philosophic tradition in the same line with Indian philosophy (Darshana) and Chinese philosophy (Confucianism). In his view, this philosophy can be named Afraa which he called Theistic Humanism because though it harbours myths and religious world-view, it is governed by the paradigm of modern science. (Dukor, 2010: p. 91) His notion of African philosophy as Theistic Humanism opens the way for a new study of African philosophical idea of man and the universe from the dualist angle.

In the Yoruba mythology, God exists because the workings of nature and the force behind it are not in the hand of any mortal man. And due to the regularity exhibited by nature Africans assume that God exists. The Akan of Ghana call him Odomakoma: he beyond whom there is nothing, the Yoruba refer to him as Olodumare or Eleda: the father of mystery and creator respectively; to the Ibos of Nigeria, God is Chukwu: the great source (Okedairo, 2006: p. 41). But since nature is so verse with different aspects, God needs the services of helpers, who can handle these aspects. So, he has some lieutenants, who were given the task to see to the regular workings of the universe. However the delegation of duties to our own mind can be as a result of the rebellion of the gods and their agitation to be given responsibilities as stated in the earlier story, which suggested that God listen to the complaints and voice of its people, if properly channeled.

While Orunmila is the god of divination and knowledge, it is the duty of every devotee to inquire from Orunmila the knowledge of life especially as it pertains to their own existence. Also, there is Ogun who is the god of iron. So, all those who work or earn a living by the use of machines and iron would incur his grace and knowledge for success in their endeavour.

The farmers have Orisa Oko to thank and make supplications, while Sango is the god of thunder and justice. In Yoruba mythology, all these gods were sent by Olodumare from heaven to order the earth and populate it. And, as long as they are successful, there is no need to call the Supreme Being except to thank him for making his servants or divinities available for human emancipation.

Though these gods are heavenly beings, they were also historical beings. The orisa, (gods) according to Okedairo are 
numberless, some journeyed from heaven, some were revealed by oracles and others deified or canonized on account of their lives (2006: p. 43). That is why they have both spiritual and physical representations. These divinities are, therefore, not far from the affairs they govern. They lived among the people and impact on their lives directly. Olugbon, Aresa, Alara of Ilara, Orangun of Ila, Ajero of Ijero, Sango, Ogun, were kings who ruled their people with virtue and as such became divinities. Unlike the western idea of angels who are not historical beings, even Jesus Christ that came as a human being, is still seen as God himself who simultaneously occupied heaven and still lived on the earth. And most of his deeds are miraculous because he gets things done by mere pronouncement or fiat.

Such deeds like those of Jesus were not attributed to any of the Yoruba gods, who mainly depend on herbs, roots, leaves, practical things, even the use of incantations is not potent without the use of charms and amulets which are physical objects, to help their people from their problems. This is significant because these physical objects use for transforming human lives are within the human universe, and as such readily accessible even if the gods are no more around.

Sodipo Olubi (1973) mentioned that in the Yoruba idea of Cause and Chance, the belief of the Yorubas is that an event happens ordinarily when it involves no human being but if a man is at the centre of the event or if $s / h e$ is hit by fortune or disaster, a god must have a hand in it, which typifies a kind of occasional theory. Malebranche exposes that physical events and mental events are parallel such that there is no interaction in terms of causality between them but if God is willing at any particular moment, he can produce what he will when either a physical or mental event takes place. But because of the contiguity in time and space, we think that either a mental event or physical event is the cause of another event rather than the will of God. To the Yoruba (African) the ultimate causation of failure or success is therefore spiritual, not physical. Sodipo (1973: p. 18) explained that the Yoruba ordinarily believe a coin would turn head or tail and that the chance is $50-50$ or $1 / 2$. But if there is a need to determine who will win a prize by the use of a coin, then the gods or God must support the person who got it right.

However, Africans believe that God do not just intervene on occasion except you invite him by making sacrifices and praying towards the aspects of life you want him to. In addition to being ministers and intermediaries of God, the divinities also act as guardians and policemen of public morality (Idowu, 1979: p. 47). And as agent of sanction they contribute to the obedience of the law as mentioned by Glaucon while reflecting on the effects of the Gyges ring in the Republic (360d).

If an average Yoruba man makes propitiation and sacrifice for intervention and his/her divinity fails to accede to his request, the Yoruba feels the divinity is useless, he can then go to the Supreme Being to talk to his god or to override the god if the god is unjust in his judgment against this follower. If by any means it was discovered that the god acted unjustly, the devotee has the right to abandon him/her and move ahead to some other god. A Yoruba proverb says "Orisa bo le gbemi semi, bi o se bami" meaning "if the god cannot help my case, he should not make me worse." God or the gods in African mythology do have their own limitations and for this reason, it is not a style in African religion to stick to one way of life. It is possible for one god to succeed where another has failed. Service delivery is therefore important to the gods. So, it is rare or impossible to see a self- proclaimed atheist in traditional Africa.

The operation of Chance itself is interpreted as Cause in the attempt to answer the question: why does this happen to me now? Why are some individuals very fortunate and why are some so unfortunate? The consistency of chance and the consistency of cause cannot but have the same meaning to an average human being who is looking for a consistent explanation of things in the universe. The consistency of chance must then be a manipulation and the consistency of cause must also be a manipulation. Since these manipulations are not verifiable physically then they must come from either God or the gods. Sacrifices to the gods at times yield no result because required human effort is either lacking or inadequate. Also human effort fails because of lack of prerequisite divination and sacrifice to the gods. What some people therefore called chance or accident does come from somewhere. Richard Wiseman (2003: p. 3) confirmed this position in his paper titled The Luck Factor that:

People generate their own good fortune via four basic principles. They are skilled at creating and noticing chance opportunities, Make lucky decisions by listening to their (intuition), create self-fulfilling prophecies via positive expectations, and adopt a resilient attitude that transforms bad luck into good (emphasis mine). So, what we call chance is the inspiration or revelation man capitalized on to achieve his aims.

God is the "rewarder" of good and bad in the society. He is also seen as the provider of wealth since he is the determiner of human destiny, though human effort is required but this effort is nothing if it is not in accordance with God's plan. Dukor also said that the issue with African Philosophy is that "it has to start from the religious world-view of the African” (Dukor, 2010: p. 92). Going by the above submissions one can say that African world-view takes its source from the belief in God or the gods.

\section{The Western Idea of God}

The Western idea of God is torn among idealism and materialism. In Anselm's ontological argument, he proposed that in the stratifications of beings there must be a being which nothing greater than can be conceived both in the mind and outside the mind. This being is called God. This ontology thus did not take care of content or the personality of God. Following the same rational tradition, Descartes postulates the infinite being from knowing that there are finite beings.

The idealist cum rationalist conception of God does not actually specify any attribute of God except that he is the first and greatest being. And most Western materialists cum empiricists abhor the idea of God. That is why Western philosophy tends towards the scientific orientation.

The aim of Western science is to conquer nature and subdue the earth as the bible commanded man in the beginning. All the explorations and exploitations of other continents by the Western world and inventions, attested to this position. We are not saying that there are no inventions or scientific orientation in Africa prior to Western civilization, even as this was present, it was a science that is devoid of capitalist intent. This philosophy believes that man has what it takes to change and maintain his universe without having the intention for individual ownership or commercial gain.

The Christian idea of God has great influence on the western 
conception of God. The idea that God is omnipotent, omniscient, omnibenevolent can be traced to the Jewish anthropomorphic conception of God. Here also God is not working alone, he has angels and archangels who assist in the day to day running of the earthly and heavenly affairs.

The intervention of God in human affairs is only warranted in the receiving of inspirations and perhaps revelations where humans have failed or yet to focus. Human beings by prayer can also call for his help in the affairs of the universe, government, or personal issues. Christianity (except Catholics) does not allow supplications to angels except to God through Jesus who is seen as both God and the son of God simultaneously.

What however is puzzling about these beliefs is the question of freedom and determinism or the problem of destiny, of whether destiny actually operates. If it does, is it changeable or not changeable? And if destiny does not operate, what is the role of God in the events in the universe. The question of destiny in western idea of man and the universe has not been settled. The events in the bible can be interpreted to support or attack the question.

One is also fascinated by the Christian ethics summarized through Biblical events by Joseph Fletcher (1966) as relativistic but holding at the same time the laws of Moses which is absolute and positivistic in nature. The Law of Moses, which is the Ten Commandments, was summarized and reduced to two by the leader of the Christian faith, Jesus as 1) Love God and only him shall you serve; 2) Love your neighbour as yourself.

This reduction brought out the idea of theistic humanism as exposed by Dukor. On one hand, humans are enjoined to love God, which is theism while on the other hand humans were told to love one another, which is humanism. This is Theistic Humanism which to us is in consonance with Western orientation rather than African.

However, the idea in theistic humanism to our mind should not be to love (value) God and love (value) man at the same time, but to choose which of the love (value) would accommodate the other. In other words, is the love (value) of God included in the love (value) of man? Or is the love of man included in the love of God?

\section{The Idea of Theistic Humanism and Humanistic Theism Exposed}

Theistic humanism would be a humanism that accommodates the love (value) of God or the worship of God. But it would be like denying the power of God and at the same time accommodating it. If this is the case, one needs to ask, if humans can solve their problems, what role would God play? The answer perhaps can be that God would be responsible for giving human beings inspiration on problem solving or that he would serve as an umpire, to see which human being is doing or not doing the job of salvaging the common heritage (universe). The bible says that a time is coming when God would deal with the destroyers of the universe. But one can ask, is receiving inspiration from God not the same as taking order of: thou shall or thou shall not...from him? Western Philosophy mostly explained this by making allusion to human intuition rather than saying that God is responsible for this inspiration. So, to them, both human intellect and intuition are enough to solve human problems rather than making recourse to a God or gods. But to the average African man inspiration comes from God or the gods.
Humanistic theism would involve the attempt to show that belief in God and following his laws would result into good life for man. Here obedience to God can result into man's selfdescription and realization of needs and interests. One can blame human suffering on the disobedience of Adam and Eve in the garden. And accept the explanation that until man returns back to God there is no respite. God makes the rules in the interest of man.

To the yoruba (African), Destiny alteration is done by the attitude of the individual concerned. A good destiny warrants obedience to God or the gods and good behaviours: conforming to rules and regulations and using our powers to the benefit of others. While bad destiny warrants disobedience and bad behaviours: disobeying rules and doing harm to others. Moral rules in the Yoruba culture are aptly tied to taboos, where the gods are the agents of sanction. So, the fear of sanction from the gods who are ubiquitous engendered good character from the people. Incidentally character (iwa) is personified as the first wife of Orunmila the god of divination. This brought out a kind of relationship or affinity between morality and epistemology.

The Yorubas believe there are $600+1$ divinities. The addition of the 1 is to show the principle of elasticity by which they account for newly deified orisa (god). The belief is that every individual has the potential to become a divinity depending on the use of one's attributes. (Abimbola, 2006: p. 50).

The above point also constitutes the goal of education in Yoruba culture. It has been argued that the essence of education according to the Yoruba is to make a student become an Omoluabi or Omoluwabi, meaning, the child of God or the good child. And to become a child of God requires sound knowledge and good character (obedience to rules, discretion in state matters, wisdom and avoidance of extremes). In other words sharing godly attributes is a prerequisite to take part in state and societal affairs. This is expressed in the Yoruba proverb which says ti omode bamo owo we, yio ba agba jeun' meaning if a child has understanding would be in company/ circle of elders.

This paper proposed that, other cultures may extract the attributes of God as the Yorubas have done and take them as factors (ideals) for development. God to us is all good, all knowing, all doing etc. but believers' behaviour these days leaves much to be desired. With the rate of suicide bombing, terrorist attack and corruption in Nigeria, and the confession of religiosity, there seems to be a contradiction. The attitudes of believers do not tally with the attributes of their God, who they look unto as the idea of perfection or goodness.

This is not to say humans should strive to be omnipotent, omnibenevolent and omniscient, but they only need to be good enough to do things to enhance peace and social development. Though we may have different idea of the road to peace and development, no idea of peace and development can accommodate the killing of innocent souls and the looting of the nations' commonwealth. If we can't be all good, we can be good more than we are, if we can't be omnipotent, one can be potent in all his/her duties. This way of expressing our belief in God would ultimately favour humanistic approach to life based on our idea of God. This to us is Humanistic Theism.

\section{Conclusion}

Humans strive towards perfection and the ideals of God. 
Even humanism is an attempt to show that man is intelligent (knows), powerful, and good. As we mentioned earlier humanism is a reaction against religious beliefs that endanger man and suppress the development of his society on the idea that man is powerless and ignorant and as such cannot help himself. More needful than faith in God is that man can give love, justice peace, and all his beloved values embodied in human relations. It is not as if man has succeeded, but it remains as an ideal that man should pursue.

Though one cannot say that God too has succeeded in promoting these ideals but perhaps it is because we have not been able to separate what God has done, from what religious leaders and priests are doing and have done. But one can agree that if there is any being who could possess these attributes it must be a perfect being. Man, as it is generally agreed is not a perfect being though he strives towards it. Humanistic Theism therefore, rests on the assumption that the interest of man is paramount, but the gods are agents of development who are there to serve human purpose and needs.

This is why divination or revelation is important in human life to determine the direction one can take. With a divination oriented religion like the Yorubas, no Yoruba will attempt to do anything worthwhile in life without consulting ifa, which according to Bolaji Idowu, is regarded as "unfailing source of comfort" (1979: p. 84). From cradle to death, ifa is the guardian and guiding god that shows the way to peace and justice. In every area of life, a god is there for the Yorubas to consult or emulate in the attempt to succeed.

This paper has shown that humanistic theism like theistic human is a dualist account of man and the universe which believe that the spiritual world exists as much as physical world and that the relationship between them is mutual but the supernatural is superior and as such the centre of value to man. However, the supernatural takes into consideration the needs and wants of human beings. In other words the gods exist for man and his universe rather than for themselves alone. Only that man must make sacrifices to the gods.

One can only hope that the intention of this paper has been achieved in showing that Humanistic Theism as African philosophical world-view is based on the idea of a benevolent, potent and scientific God who is a paradigm for development; a God who believes in individual potential and power, who thereby delegated his duties to man and the gods. It follows that, as we strive to help others and become harmless to the universe, we become candidates for canonization or deification.

\section{REFERENCES}

Azenabor, G. (2010). Modern African philosophical theories. Lagos: Byolah Publishers.

Fletcher, J. (1966). Situation ethics: A new morality.

Grube, G. M. A. (1992). Plato republic. Indianapolis: Hacket Publishing co.

Honer, S., Hunt, T., \& Okholm, D. (1999). Invitation to philosophy (8th ed.). Canada: Wadsworth Publishing Company.

Idowu, B. (1979). Olodumare: God in Yoruba belief. London: Longman Publisher

Kola, A. (2006). Yoruba culture: A philosophical account. Birmingham: Iroko Publishers.

Maduabuchi, D. (2001). Theistic humanism-African philosophical tradition. Journal of Indian Council of Philosophical Research, 18.

Maduabuchi, D. (2010). Theistic humanism of African philosophy: The great debates on substance and method of philosophy. Saabruchckhen: LAP LAMBERT Academic Publishing Gmbh \& co.

Olusegun, O. (2006). Africanism. Ogun: Kofo David Graphics.

Oluwole, S. (1984). The rational basis of Yoruba ethical thinking. Nigerian Journal of Philosophy, 4-5.

Oluwole, S. (1992). Witchcraft reincarnation and godhead (Issues in African philosophy). Lagos: Ark Publishers.

Sodipo, O. (1973). Note on the concept of cause and chance. Second Order: An African Journal of Philosophy, 2.

Velasquez, M. (2005). Philosophy: A text with readings (9th ed.). Belmont: Thomson Wadsworth.

Wiseman, R. (2003). The luck factor. The Magazine for Science and Reason, 27. http://www.csicop.Org/si 